\title{
EИHTE3E
}

2017, бр. 11, стр. $39-71$.

UDK 371.31

Review Paper

doi:10.5937/sinteze6-13812

\section{CONTEMPORARY SOCIETY CHALLENGES OF INTEGRATIVE TEACHING}

\author{
Marija, M. Jovanovic ${ }^{1}$,Vesna, S. Kovcic ${ }^{2}$
}

\begin{abstract}
This paper discusses the characteristics of integrative teaching as an innovative teaching model which creates opportunities for comprehensive development of the student's personality through the adoption of comprehensive knowledge and development of functional abilities of students. Based on the principle of functional connectivity of meaningful, cognitive, psychological, organizational and sociological aspects of teaching, integrative teaching offers many opportunities for good quality educational activities. However, the complexity that arises from the abovementioned traits of integrative teaching entails some difficulties in the process of its planning, programming and implementation. It is important for the teaching process to have a good knowledge of the essential characteristics and values of integrative teaching and a willingness to use successful didactic and methodical tools to overcome potential difficulties. In order to systematically emphasize the current challenges of integrative teaching, this paper approached this problem from the aspect of: theoretical definitions, didactic values, disadvantages, the implementation of integrative teaching in schools, and how integrative teaching helps students to acquire knowledge.
\end{abstract}

Key terms: didactic values; implementation; knowledge; Learning outcomes; integrative teaching.

\section{INTRODUCTION}

Focused on the adoption of comprehensive knowledge and on the development of functional skills, integrative teaching involves an innovative teaching model which enables the achievement of meaningful links between similar aspects of different disciplines (Đorđević, 2007).

\footnotetext{
${ }^{1}$ marija.jovanovic@ filfak.ni.ac.rs, University of Niš, Faculty of Philosophy

2 vesnakovcic93@gmail.com, University of Niš, Faculty of Philosophy
} 
Mutual integration of disciplines and understanding the problem from different angles contributes to the overall learning process which is inherent to human knowledge and which is more than the sum of individual parts. In this way, such knowledge is acquired in the classroom which represents the system where these new learnt facts affect the existing ones creating a new, more advanced, and more complete knowledge system. The author Drobnjak (2007) claims that integrative teaching process involves the achievement of principles where all elements of the teaching process are linked and create functional relationships which further on build a comprehensive and harmonious picture. As it can be seen, the key category of integrative teaching is the creation of connections and relationships, that is, linking educational content from different school subjects. Given the nature of links created, we can talk about the following kinds of interdisciplinary integrative links and relationships: direct interdisciplinary links, direct interdisciplinary research links, mentally mediated links and indirectly applied links (Vilotijević \& Vilotijević, 2008, p. 144). The first type of link refers to the integration which occurs when knowledge acquired from one school subject is based on the contents from another course. The second types of links, direct interdisciplinary research link is established when the research of one general problem is based on a consideration of different disciplinary approaches. Mentally mediated links are created when using different courses could form the same skills and abilities that are necessary for the student to perform future professional activities. Links that indicate the possibility that the concepts acquired from one school subject could be applied in other subjects are called indirectly applied links.

Based on the different types of links that are established between school subjects or disciplines, different levels of connection can be achieved in integrative teaching. According to the author Spremić (2007), the first and the lowest level of integration refers to the formal level of integration. In other words, students attend classes from different subjects without the ability to connect the knowledge achieved from these. This level of integration is the most common one in reality. The second level is more advanced and it indicates the possibility that students can acquire knowledge of a specific topic from different aspects; however, the integration of learning material is left to them, without any systematic influence on the creation of the image about the topic that is being studied. The next level wants that teachers and students get involved in the integration process based on the model of the lectures conducted by a 
team of experts. Regardless of integration, teachers retain autonomy as representatives of their discipline. The essential level of integration refers to the tendency of teachers and students to contribute to the construction of a new whole that would consist of interrelated facts learnt from different disciplines. The newly established knowledge system consists of all the knowledge from all disciplines that were studied. Most authors agree that the three most common forms of integration are: full, partial and block (Vilotijević \& Vilotijević, 2008, p. 147; Drobnjak, 2007). The first type refers to the merging of different teaching contents into a single learning course. Partial integration indicates a joint processing of various learning materials that are similar by using appropriate didactic material. Block integration builds programmed and autonomous blocks or segregates common parts within the program which will be interactively processed. The prerequisite for successful implementation of integrative teaching, especially block integration is the development of flexible timetables which would allow for an adequate time frame for the implementation of this type of learning.

The essence of integrative teaching, as we have seen, is the thematic approach which enables students to acquire knowledge from different courses that are linked to each other in a unique way and which form a complete picture of reality. In that way, students are given the opportunity to build concepts seeing them from different perspectives. These facts indicate that the integrative approach provides students with the opportunity to integrate the acquired knowledge, their experience and to actively and creatively think when learning.

Based on the study of literature we can conclude that numerous attempts to merge the contents of various subjects are nowadays called integrative teaching, which is why there is a huge number of different levels of integration that often have no substantive meaning or purpose. For this reason, it is necessary that teachers are made aware of the ways to link the contents of different subjects in order for the integration to be done at a substantial level. Also, it is necessary to use integrative teaching to teach the students from the earliest age to learn and to acquire comprehensive knowledge and to perceive the world based on integrity and unity.

\section{DIDACTIC VALUE OF INTEGRATIVE TEACHING}

Integrative teaching is one of the innovative models of teaching that helps achieve a developmental model of education with its didactic 
values. When analyzing the didactic value of integrative teaching, it should primarily be started from the actual objectives of the lessons, that is, it should be understood what the goal of the integration of learning material and content is. The objectives of the lessons may be set in many ways and operationalized through adequate learning tasks. Integrative approach primarily contributes to building a comprehensive picture of reality, the kind the students encounter in real life, thus thorough learning is achieved, and divergent way of thinking and originality are developed.

The findings that didactics has collected to the present day show that the use of certain teaching approaches helps students not only to better adopt the knowledge from the prescribed curriculum, but they also enjoy the lessons more, which is a very important component for future learning (Bretz \& Thompsett, 1992, p. 941-951). For this reason, didactics advocates the use of different teaching approaches, that is, the selection of the appropriate approach to study a particular teaching unit. The knowledge acquired by the student is not divided into scientific disciplines, into the courses, but these should rather be fitted into an overall picture of the reality experienced by the student. Integrative learning approach helps create such a picture of reality. It provides an overview of a problem from various different angles. In this way, a comprehensive context for learning is formed that leads to thorough learning and long-term memory (Spremić, 2007). Supporters of the integrative approach advocate that the borders among the courses should not be the borders when organizing the teaching process (Drobnjak, 2007). Many authors advocate the integrative approach to education and claim that more sophisticated level of learning cannot be achieved if the school subjects are divided (Klein, 2005). Certainly, the teaching process should equally respect an analytical approach, that is, the division of subjects and acquisition of knowledge only within these as such, as well as the synthetic approach which involves the creation of new knowledge through the knowledge acquired from different subjects. But, when the teaching process consists only of divided courses, that whole process insufficiently contributes to the creation of a comprehensive picture of the world and with an irrational expenditure of time and energy, both of teachers and students. The fact that students are enabled to acquire knowledge looking at the problem from different angles contributes to a higher quality of knowledge which is suitable for transfer and it also encourages students to have an active attitude towards knowledge they have gained (Andrić \& Spasojević, 2012). 
Traditionally organized teaching that advocates the division of courses certainly has its advantages. However, studies have shown that a different form of teaching process organization contributes to the achievement of the goals set, which are ignored in the traditional approach; however, these goals are nowadays said to be imperative. Integrative approach, as an innovative way of organizing teaching, is based on the belief that learning conditions which it promotes and creates, reduce or completely eliminate the traditional barriers to learning and allow students to use not only their cognitive potential, but to achieve comprehensive learning (Bretz \& Thompsett, 1992).It is well-known that students more successfully master the material if it is linked to their experience and if it meets their needs and goals (Buljubašić Kuzmanović, 2007). The knowledge that students acquire in integrative lessons is close to knowledge that they gained from experience when socially interacting. The overall picture that is created through understanding of acquired knowledge creates in students firm learning skills and durable knowledge. Such knowledge is valuable and suitable for transfer and practical use.

Practical use of knowledge is one of the roles of acquired knowledge. The requirements that the modern world sets when entering the world of work are getting more and more complex and require comprehensive knowledge and their full understanding. Advocating such education where knowledge is acquired partially, without any insight into the whole, does not meet the requirements of modern society. What also speaks in favour of these facts is that the knowledge acquired from divided courses is not really usable in real life (Vilotijević \& Vilotijević, 2008).Man develops from the integrity and mutual interaction of all elements. Educational system should be designed in this way in order for the knowledge acquired to be useful. The traditional way of organizing teaching which is based on the adoption of knowledge in its final form and within the course division environment, cannot prepare the students for the demands of modern society, which is transforming rapidly (Đorđević, 2007; Spremić, 2007).Didactic value of integrative teaching is reflected in the functionality of the knowledge acquired and the competencies that are only acquired by insisting on this way of looking at the learning material.

One of the goals achieved by the integrative approach is the divergent thinking. Divergent thinking tends towards finding a large number of original and diverse solutions. In order to reach this objective, it is essential that teachers encourage students to generate as many ideas 
as possible in class. Integrative approach allows the students to create original ideas through problem-solving situations, which must be supported by teachers. Integrative teaching requires active students. It is not in the least based on the mere transfer of knowledge, but entirely on problem solving, asking questions and an active attitude towards the learning material (Đorđević, 2007). The value of integrative method can be deduced from the fact that certain problems cannot be solved from the perspective of only one discipline (Spremić, 2007).It is essential that the teacher encourages students to look at things from different perspectives and to solve problems in different ways. It is important that students understand that one problem may look completely different if seen from different angles. Encouraging understanding implies that teachers in class support the students to observe the issues from multiple perspectives, to question the existing knowledge and to explore. Didactic value of the integrative learning approach is reflected in the rationality when using time and resources for the teaching topics. For the purpose of integrative approach, thematic planning is done. Thematic, integrative planning is interdisciplinary and comes down to thematization of curricula (Vilotijević, 2000). Thematization creates a framework for the integration of teaching material, that is, it links one teaching area to another, providing the possibility of looking at the problem from different angles. Correlation of certain courses helps save time and contributes to building natural, social and other areas to research and learn about. Use of the integrative approach helps optimize the teaching process. For the purpose of rationalization, the adequate selection of the methods and tools is done, in accordance with the didactic and logical structure of the chosen teaching material that is being studied thematically.

The abovementioned facts support the facts that subject division advocated by traditional school neglected the specific goals that are necessary for the modern society. Integrative teaching is an innovative type of learning which provides insight into the whole and the core of the studied material, and which develops cognitive skills necessary to respond to the demands of modern society. What is imposed as a necessary step in implementing integrative teaching is that students from a very young age get used to the integrative teaching and to evaluate the information obtained during such learning process, and on the other hand, to increase cooperation among teachers in order for integrative learning to be used in the subject, and not only in class teaching. 
Didactic values of integrative teaching cannot be disputed. However, it is important to emphasize that a prerequisite to achieve these values is not to accept exclusivity and one-sidedness in the teaching process. Therefore, the most common limitation of integrative teaching is often said to be the danger of one-sidedness with respect to advocating only one approach in the theory and practice of integrative teaching (Vilotijević \& Vilotijević, 2008; Schaefer, 2005; Brophy \& Alleman, 1991, pp. 66-67; Polić, 2006, pp. 61-72). In support of this view is the fact that science is divided into scientific disciplines in order to understand its logical structure, and based on this it was didactically developed and translated into the school subjects (Schaefer, 2005). The goal of the study of science in the aforementioned form is that students are able to observe logical structure of scientific disciplines. In this sense, Vilotijević (2006) believes that the complete process of differentiation is followed by the richer and more comprehensive integration. A complete differentiation of science should be followed by the process of integration in order for the students to be able to fully understand a scientific discipline and not only its logical structure. Although the end goal is the integrative approach, human knowledge has certain limitations that imply the necessity to combine analytical and synthetic knowledge in the pursuit of deep understanding.

Apart from this restriction, the following are some shortcomings of the integrative approach:

1) Insufficient skills and didactic and methodical competence of teachers to perform integrative teaching. Integrative approach to teaching sets requirements for the involvement and creativity of teachers to create a problem-solving scenario that will intellectually engage the students, and which will help students acquire deep and lasting knowledge (Jones, 2010). Teachers often do not have the pedagogical and didactic and methodological skills necessary for successful planning and execution of integrative teaching.

2) The traditional specialization for certain disciplines and inadequate knowledge of other disciplines is a common difficulty for the execution of integrative teaching. Teachers often do not have broader knowledge besides the knowledge they need for the subject they teach. The integrative approach requires teachers 
who: have a broad general knowledge, good knowledge of related scientific and teaching disciplines, good knowledge of curriculum and school programs being used in the respective school.

3) Difficulties in achieving coordination among teachers are often an obstacle to the execution of integrative teaching. Teachers are often not ready and do not have enough skills developed to teach a certain topic through teamwork. They are difficult to adapt to the newly created work method. In this sense, it is certainly easier for teachers to stick to the school subject division due to the noncompliance of the different subjects' programs, then, due to the need for modification of the timetable, and because of the preparations for the integrative approach which need some time (Bretz \& Thompsett, 1992). The study of the previously mentioned authors has shown that administrative changes and enthusiasm of teachers led to better results in the implementation of the integrative approach.

4) Inefficiency in terms of time as one shortcoming of integrative teaching stems from the complexity of its planning and implementation. It requires a lot time and work to adapt the curriculum, and to coordinate and integrate teaching material. Moreover, it is necessary to take the time to check the objective and subjective abilities of students, working conditions and opportunities and requirements of other colleagues.

5) The realization that integrative teaching takes away the autonomy from the teacher is another difficulty when implementing integrative teaching. Teachers often have an incorrect perception of their autonomy and believe that this is the most important aspect of all. It is hard for the teachers to relinquish their primary role and importance and they are not ready to share it with other colleagues. The issue of teacher autonomy is often associated with the so-called professional egoism that has an adverse effect on teamwork and prevents the execution of a quality integrative teaching.

\section{IMPLEMENTATION OF INTEGRATIVE TEACHING IN SCHOOLS}

For many decades now, schools have been working based on the fixed, solid program that is not open to change. Any novelty to be introduced in the teaching process requires certain modifications, that is, the provision of adequate conditions for its implementation. Successful 
execution of the teaching process based on the integrative approach requires certain conditions, methods and strategies.

Given that most of the changes are introduced in the education system from top to bottom, the first and foremost step towards the implementation of integrative teaching is the existence of educational strategy that will support the integrative approach (Đorđević, 2007). The fact is that there is no such concept in our country, so the implementation is left to the teachers themselves. It is up to them to exercise integrative approach during lessons planning. Aspirations towards the integration of teaching material and implementation of this innovative model in the classroom depend primarily on the enthusiasm of subject teachers. However, class teachers are in a more favourable position during planning process because they organize the entire lesson for their class (Drobnjak, 2007). This allows class teachers not to have to strictly adhere to the timetable, but rather use the rotation of lessons to merge a few lessons and to implement integrative approach. They should serve as an example to subject teachers on how to execute integrative learning.

If there is no concept ready by the government, a good way to introduce the integrative approach is to have the support from the school principal for this type of innovative work (Spremić, 2007). The principals, together with expert associates, can promote this work method in teacher councils, thereby affecting the views of other teachers about the values of integrative teaching. Furthermore, they could use their didactic material to assist their colleagues in improving their educational work. The involvement of a large number of class and subject teachers provides more options for the modification of timetables to the pleasure of all (Đorđević, 2007).

The actual process of integrative teaching implementation consists of planning and execution. Considering that the integrative approach is based on the correlation of more topics or more courses, planning phase will be explained in detail.

\section{INTEGRATIVE TEACHING PLANNING}

Teaching, in the broad sense, involves thorough planning and programming of teaching material. Planning process is based on setting the didactic and methodical elements of the teaching process and providing the necessary conditions so that teaching could be executed in a systematic, organized and purposeful way, in accordance with the established rules and principles. The development of science and its 
division into separate scientific discipline allows them to be didactically shaped and presented in the classroom through individual courses. However, the accumulation of scientific knowledge leads to a large number of facts that will be more rationally overcome by integrative approach. For this reason, lesson planning should also include thematic, integrative approach. The initial step in planning an integrative approach is the insight into the School program, that is, the objective and material resources for the execution of integrative teaching should be examined.

Later on, planning process should analyze the Annual thematic plan. As it can be inferred from the name, teaching programs in our country are themed, that is, they are composed of different didactic and logical sections. This plan is tentative and contains general requirements to be followed in the teaching process (Vilotijević, 2000). It defines the topics to be covered during the school year, work dynamics, the required number of classes to cover each topic; it helps choose appropriate tools, methods and resources. This document is used by teachers for the thorough preparation of teachers of individual lesson plans that will be used. In our country, the most common lesson plans are monthly work plans that show more realistically what will be taught and how during a specific month.

The use of the integrative methodological approach in teaching requires a completely new form of lesson organization and planning. Different authors have different opinions on how to plan integrative lessons. According to Spasić-Stošić (2016) work plan for the preparation and execution of integrative teaching should follow these steps: selection of the appropriate topic, definition of the objectives to be met by treating that certain topic, determine the order of the goals and concepts to be covered and plan appropriate activities for every topic, select and prepare material and other resources necessary to cover selected topics, describe the activities, evaluate and draw a conclusion on the covered topic. The author Walsh (Walsh, Collins, A. \& Hitrec, 2002, p. 146) states that the application of integrative planning includes the following steps: select a certain topic, initiate brainstorming about the project, have adequate knowledge of the topic, gather material necessary to cover the topic, plan the lesson.

As it can be concluded, although the authors identify different steps in planning an integrative lesson, they mostly agree on the actual procedures that should be followed when planning an integrative lesson. The difference that can be found in the opinions of authors mentioned with regards to the planning of integrative lessons is only related to the 
detailed execution of the lesson, that is, to emphasizing general indication related to the organization of the actual lesson. Moreover, both authors insists on the creative work of students who will use their experience to link the facts and teaching material and in that way create a large number of ideas that will then be examined and feedback on results of their work will be provided by teachers, as well as on the quality of brainstormed concepts.

As Vilotijević (2006) points out, using the integrative teaching approach requires planning such lessons which will drive the acquisition of systematic knowledge, experience, development of creative activities and the formation of attitudes and views. Based on the didactic structure of the topic which is the subject of study, the selection of appropriate methods, forms, tools and methods is required. Considering that the position of students is significantly altered compared to the traditional classes, methods that require students to be active are desired. That is why the prevailing methods are dialogues or conversation, as well as problemsolving and research methods. Based on these, the following types of tools are predominantly used in integrative lessons: problem-solving, researchbased and experiential learning, etc.

The abovementioned lesson organization indicates the abandonment of frontal teaching, because the tendency is to have group work or work in pairs, and then individual work. Therefore, the author Buljubašić-Kuzmanovic (Buljubašić - Kuzmanović, 2007) points out that in the beginning, in the brainstorming phase, the integrative lesson is focused on group work, while later on it tends to encourage independence and self-responsibility. Classes based on the integrative approach start from the knowledge that students already have from their experiences, and that knowledge should be used as a basis when creating integrative lessons plans. By using the principles of moving from the known facts to the unknown facts, creates a sense of pleasure in students because they feel competent at the beginning of the learning process which then creates the need in them for continuous learning.

Correlation between different disciplines and encouragement of numerous skills of students obliges teachers to take into account the different media and sources of learning when planning lessons. Learning can be enriched and made more interesting if proper teaching resources and tools are chosen based on the didactic and logical structure of the topic and work methods. In this sense, as the canter of various resources, school library has an important role in the integrative learning process (Spasić-Stošić, 2016). Auditory, visual and kinetic tools are used to direct 
students' attention. By activating these senses, specific knowledge can be acquired which will thenenrich the picture of objective reality.

Based on these facts, it can be clearly concluded that it is much easier to plan, organize and conduct traditional lessons. However, if we do not disregard the fact that the integrative approach to the teaching topics is of the utmost importance to accomplish planned educational goals, integrative teaching model will certainly not be missing from the lessons.

\section{LINK BETWEEN INTEGRATIVE TEACHING AND LEARNING OUTCOMES}

Integrative learning is essentially a synthesis of the learning process through multiple experiences, integration of meanings and creation of new meanings and knowledge. The question that arises from the integrative learning is what its outcome is. The intention of every learning process, integrative process included, is expressed through the goals and outcomes. Learning outcomes are clear descriptions of what a student must know after a certain learning process. Objectives depend on the outcome definitions, and vice versa. The complex outcomes such as integrative learning are often difficult to define in words. When defining outcomes, the main problem is too general requirements that practically cannot be verified. They can be defined operationally, that is, it can be determined what to do when we strive to a certain outcome. Every task can be assigned to an outcome (Huber, Hutchings, Gale, Miller, \& Breen, 2007). It is necessary to engage experts from every field to provide operational definitions of integrative learning process outcomes. In this paper, the learning outcomes from the integrative approach will be considered based on the didactic value of integrative teaching. The outcomes, that is, the results that are achieved with integrative teaching are primarily reflected in the comprehensive view of the problem from multiple perspectives and in the practical use of knowledge.

The research by the author Himbeault - Taylor (Himbeault - Taylor, 2011) suggests that the essential learning outcomes are based on the organized processes of integrative learning. In other words, as already stated in the previous parts of this paper, integrative teaching is based on the experience and prior knowledge of students that contributes to students' satisfaction and triggers continuous learning. In real life, in the classroom, this is achieved by stating the intended learning outcomes, creating intentional structured learning opportunities in order to meet the goals and achieve active thinking, and to link the acquired knowledge 
with experience. Integrative teaching offers the possibility to interweave different outcomes such as problem solving or critical thinking, as well as to establish links and relationships between some disciplines (Huber \& Hutchings, 2004).

In-depth learning is seen as one of the didactic values that is achieved through the execution of integrative teaching. Several studies indicate that in complex areas, integrative-based, in-depth learning has a positive effect on learning outcomes, and as a result, these areas have altered teaching practice, increased use of knowledge and therefore improved results (Laird, Shoup, Kuh, \& Schwarz, 2008). If the learning process includes cognitive, affective and experiential tools, it is more likely that material taught will become truly integrated (Himbeault Taylor, 2011).This author states that improvements of learning outcomes have an important role in promoting integrative learning. If the integrative approach proves to be better in meeting the objectives and outcomes of the educational process than the traditional approach, teachers and students themselves will be more motivated to implement integrative teaching.

It can be concluded that the values of integrative teaching in terms of learning outcomes can be checked through the practical test of certain tasks, where each task would correspond a particular outcome. However, setting up a large number of complex outcomes requires the teacher to adapt the lessons, methods and tools to those outcomes. Integrative learning can respond to the requirements that the educational process sets in terms of the accomplishment of outcomes because it synthesizes cognitive, emotional, social and active component in students.

\section{CONCLUSION}

The presumption of the efficiency of modern teaching is to base it on the modern models of teaching and the developmental education model. One of the modern teaching models that ensures the quality and effectiveness of teaching is the integrative teaching. It assumes there is an understanding of different aspects of one problem, from different angles, and as such integrative teaching includes: active learning, long-term memorizing and linking knowledge in a meaningful whole. Rejecting the traditional division of school subjects, integrative teaching includes a thematic approach and problem-based learning in the classroom. In that way, students acquire comprehensive knowledge and develop functional skills which are the basis for the full development of personality. With 
adequate planning and execution of integrative teaching, in-depth of knowledge is acquired, forgetting of facts is prevented, active attitude is developed as well as the creative potential of students, and a comprehensive view of the world is formed. As we had already seen in this paper, the didactic value of integrative learning is large because those values are often not seen in other teaching models. What is important to emphasize is the fact that the effectiveness of integrative teaching depends on a good knowledge of its main obstacles, that is, the difficulties that may arise, which is why it is necessary to train the teachers to be able to use adequate didactic and methodological tools to successfully overcome these difficulties. Contemporary challenges of integrative teaching, explained in this paper through their basic features, didactic values, shortcomings, implementation in the classroom and links with the outcomes of teaching are the basis on which teachers can build the integrative teaching.

\section{REFERENCES}

Vilotijević, M. (2000). Didaktika 3- Organizacija nastave. Beograd: Naučna knjiga; Beograd: Učiteljski fakultet.

Vilotijević, M., \& Vilotijević, N. (2008). Inovacije u nastavi. Vranje: Učiteljski fakultet.

Vilotijević, N. (2006). Integrativna nastava prirode i društva. Beograd: Školska knjiga.

Drobnjak, N. (2007). Integrativna nastava. Obrazovna tehnologija, 1-2, 81-91. 76-97.

Đorđević, V. (2007). Inovativni modeli nastave. Obrazovna tehnologija, 4,

Spasić-Stošić, A. (2016). Uloga školske biblioteke u realizaciji integrativne nastave u osnovnoj školi. Godišnjak Pedagoškog fakulteta u Vranju, 7, 381-392.

Spremić, A. (2007). Integrativna nastava. Obrazovna tehnologija, 1-2, 74-80.

Šefer, J. (2005). Kreativne aktivnosti u tematskoj nastavi. Beograd: Institut za pedagoška istraživanja.

Andrić, V., \& Spasojević, P. (2012). Korelacija nastave matematike i ostalih nastavnih oblasti u mlađim razredima osnovne škole. U: N. Vulović (Ur.), Metodički aspekti nastave matematike 2, Jagodina. Fakultet pedagoških nauka.199-212.

Bretz, R.D., \& Thompsett, R.E. (1992). Comparing traditional and integrative learning methods in organizational training programs. Journal of 
Applied Psychology, 77(6), 941-951. pmid:1468996. doi:10.1037/00219010.77.6.941

Brophy, J., \& Alleman, J. (1991). A caveat: Curriculum integration isn't always a good idea. Educational Leadership, 49(2), 66.

Buljubašić-Kuzmanović, V. (2007). Studentska prosudba učinkovitosti integrativnog učenja. Odgojne znanosti, 9(2(14)), 147-160. Preuzeto sa http://hrcak.srce.hr/23550

Himbeault Taylor, (. (2011). Engendering habits of mind and heart through integrative learning. About Campus, 16(5), 13-20. doi:10.1002/abc.20076

Huber, M.T., \& Hutchings, P. (2004). Integrative Learning: Mapping the Terrain. Washington, DC: Association of American Colleges and Universities. Preuzeto sa https://eric.ed.gov/?id=ED486247

Huber, M.T., Hutchings, P., Gale, R., Miller, R., \& Breen, M. (2007). Leading Initiatives for Integrative Learning. Liberal Education, 93(2), 46-51.

Jones, C. (2010). Interdisciplinary Approach: Advantages, Disadvantages, and the Future Benefits of Interdisciplinary Studies. ESSAI, 7(1), 76-81.

Klein, J.T. (2005). Integrative learning and interdisciplinary studies. Peer Review, 7(4), 8-10.

Laird, T.F.N., Shoup, R., Kuh, G.D., \& Schwarz, M.J. (2008). The Effects of Discipline on Deep Approaches to Student Learning and College Outcomes. Research in Higher Education, 49(6), 469-494.

Polić, M. (2006). Integralna nastava kao odgovor na suvremene obrazovne potrebe. Metodički ogledi : časopis za filozofiju odgoja, 12(2), 61-72.

Walsh, K.B., Čudina-Obradović, M., \& Hitrec, G. (2002). Stvaranje razreda usmjerenog na dijete - kurikulum za prvi razred osnovne škole razvojno-primjereni program za djecu od 6 do 7 godina - priručnik br. 4. Zagreb: Udruga roditelja "Korak po korak" za promicanje kvalitete življenja djece i obitelji.

\title{
САВРЕМЕНИ ИЗАЗОВИ ИНТЕГРАТИВНЕ НАСТАВЕ
}

\author{
Марија, М. Јовановић ${ }^{l}$, Весна, С. Ковчић ${ }^{2}$
}

Сажетак:У раду се разматрају карактеристике интегративне наставе као иновативног модела наставе којим се стварају могућности за целовити развој ученикове личности кроз усвајање целовитих знања и

\footnotetext{
${ }^{1}$ marija.jovanovic@filfak.ni.ac.rs, Универзитет у Нишу, Филозофски факултет

2 vesnakovcic93@gmail.com, Универзитет у Нишу, Филозофски факултет
} 
развој функционалних способности ученика. Заснована на принципу функционалног повезивања садржајног, сазнајног, психолошког, организационог и социолошког аспекта наставе, интегративна настава пружа многоструке могућности квалитетног васпитног и образовног деловања. Међутим, комплексност која проистиче из наведених карактеристика интегративне наставе са собом повлачи и неке тешкоће у процесу њеног планирања, програмирања и реализовања. За наставну праксу важно је добро познавање суштинских карактеристика и вредности интегративне наставе и спремност да се успешном дидактичко-методичком интервенцијом превазиђу потенцијалне тешкоће. У намери да се што ситематичније укаже на савремене изазове интегративне наставе, у раду се овом проблему приступило са аспекта: теоријског одређења, дидактичких вредности, недостатака, имплеметнације интегративне наставе у школској пракси и повезаности интегративне наставе са исходима учења.

Кључне речи: дидактичке вредности; имплементација; знање; исходи учења; интегративна настава. 
Прегледни чланак

doi:10.5937/sinteze6-13812

\title{
САВРЕМЕНИ ИЗАЗОВИ ИНТЕГРАТИВНЕ НАСТАВЕ
}

\author{
Марија, М. Јовановић ${ }^{1}$, Весна, С. Ковчић ${ }^{2}$
}

Сажетак: У раду се разматрају карактеристике интегративне наставе као иновативног модела наставе којим се стварају могућности за целовити развој ученикове личности кроз усвајање целовитих знања и развој функционалних способности ученика. Заснована на принципу функционалног повезивања садржајног, сазнајног, психолошког, организационог и социолошког аспекта наставе, интегративна настава пружа многоструке могућности квалитетног васпитног и образовног деловања. Међутим, комплексност која проистиче из наведених карактеристика интегративне наставе са собом повлачи и неке тешкоће у процесу њеног планирања, програмирања и реализовања. За наставну праксу важно је добро познавање суштинских карактеристика и вредности интегративне наставе и спремност да се успешном дидактичко-методичком интервенцијом превазиђу потенцијалне тешкоће. У намери да се што ситематичније укаже на савремене изазове интегративне наставе, у раду се овом проблему приступило са аспекта: теоријског одређења, дидактичких вредности, недостатака, имплеметнације интегративне наставе у школској пракси и повезаности интегративне наставе са исходима учења.

Кључне речи: дидактичке вредности; имплементација; знање; исходи учења; интегративна настава.

\section{УВОД}

Усмерена на усвајање целовитих знања и развој функционалних способности интегративна настава подразумева иновативни модел наставе који омогућава остваривање смислених веза између сличних аспеката различитих дисциплина (Ђорђевић,

\footnotetext{
${ }^{1}$ marija.jovanovic@filfak.ni.ac.rs, Универзитет у Нишу, Филозофски факултет

2 vesnakovcic93@gmail.com, Универзитет у Нишу, Филозофски факултет
} 
2007). Међусобно интегрисање дисциплина и сагледавање проблема са различитих аспеката доприноси целовитом сазнавању које је својствено људском сазнању и које представља више од збира појединачних делова. На овај начин у настави се стичу сазнавања која представљају систем у коме нова знања утичу на постојећа стварајући нови, напреднији, целовитији систем знања. Ауторка Дробњак (2007) под интегративношћу наставног процеса подразумева остваривања принципа у коме су сви елементи наставног процеса повезани тако да функционалним везама изграђују целовиту и храмоничну слику.

Као што се може видети, кључну категорију интегративне наставе чини остваривање веза и односа, односно повезивање наставних садржаја различитих наставних предмета. С обзиром на карактер остварених веза можемо говорити о следећим врстама међудисциплинарних интегративних веза и односа: међудисциплинарне непосредне везе, истраживачке међудисциплинарне непосредне везе, ментално посредоване везе и посредовано примењене везе (Вилотијевић \& Вилотијевић, 2008, стр. 144). Прва врста веза се односи на интеграцију када се усвајање садржаја једног предмета заснива на садржајима другог предмета. Друга врста веза, истраживачке међудисциплинарне непосредне везе, ce успостављају када се истраживање једног општег проблема заснива на разматрању са више различитих дисциплинарних приступа. Ментално посредоване везе се формирају када се путем различитих предмета могу формирати исте вештине и способности које су неопходне ученику за обављање будуће професионалне делатности. Везе које означавају могућност да се појмови стечени у једном наставном предмету примењују у другим предметима, називају се посредовано примењене везе.

На основу различитих врста веза које се успостављају између предмета или дисциплина могу се оставрити различити нивои повезаности у интегративној настави. Према ауторки Спремић (2007) први, најнижи ниво интеграције, односи се на формални ниво интеграције. Другим речима, ученици похађају часове из различитих предмета без могућности да се њихова знања повежу. Овај ниво интеграције је најзаступљенији у пракси. Други ниво је напреднији и указује на могућност да ученици стекну знања на одређену тему из различитих аспеката, међутим, интеграција садржаја је препуштена њима, без систематског утицаја на стварање слике о проучаваној теми. Следећи ниво апелује на наставнике и ученике да се укључе у 
процес интеграције по узору на предавања тима стручњака. Без обзира на интегацију, наставници задржавају аутономију као представници своје дисциплине. Суштиниски ниво интегарције се односи на тежњу наставника и ученика да допринесу изградњи нове целине која се састоји од међусобно повезаних знања стечених из различитих дисциплина. Новонастали систем знања састоји се од сазнања из свих дисциплина које су учествовале у његовом проучавању.

Већина аутора је сагласна да су најчешћа три облика интеграције: потпуни, делимични и блоковски (Вилотијевић \& Вилотијевић, 2008, стр. 147; Дробњак, 2007). Први облик се односи на спајање различитих наставних садржаја у јединствени курс учења. Делимична интеграција указује на заједничку обраду оних саржаја који су сродни коришћењем адекватног дидактичког материјала. Блоковском интеграцијом се врши изградња програмираних аутономних блокова или издвајањем заједничких делова у оквиру програма који ће бити интегративно обрађени. Претпоставка успешног остваривања интегративне наставе, посебно блоковске интеграције јесте израда еластичног распореда часова којим би се омогућио најпре адекватан временски оквир за реализацију ове наставе.

Суштину интегративне наставе, као што смо видели, чини тематски приступ којим се омогућава да ученици усвоје наставне садражаје из различитих наставних предмета који су међусобно повезани на јединствен начин и тако формирају целовиту слику стварности. На тај начин, ученицима се пружа могућност да изграде појмове сагледавајући их из различитих перспектива. Наведене чињенице указују на то да интегративни приступ ученицима пружа могућност да интегришу стечена знања, своје искуство и активно и стваралачки промишљају у настави.

На основу проучавања литературе може се закључити, да се данас због могућност да се интегративном наставом назову многобројини покушаји спајања садржаја различитих предмета,јавља велики број различитих нивоа интеграције која често нема суштински карактер. Из тог разлога неопходно је наставнике, подобније упознати са начинима спајања садржаја различитих наставних предмета како би се интеграција вршила на суштинском нивоу. Такође, неопходно је интегративном наставом ученике од 
најранијих узраста учити да стичу целовита знања и свет сагледавају са аспекта целовитости и јединствености.

\section{ДИДАКТИЧКЕ ВРЕДНОСТИ ИНТЕГРАТИВНЕ НАСТАВЕ}

Интегративна настава један је од иновативних модела наставе који је својим дидактичкимвредностима у функцији оставаривања развојног модела образовања. У анализирању дидактичких вредности интегративне наставе пре свега треба кренути од циљева наставног часа, односно од циљева којима с тежи приликом интеграције наставних садржаја. Циљеви наставног часа се могу најразличитије поставити и операционализовати путем адекватних наставних задатака. Интеграцијским приступом се пре свега доприноси изградњи целовите слике стварности, онакве са каквом се ученици срећу у стварном животу, постиже се дубинско учење, развија дивергентан начин мишљења и оригиналност.

Сазнања до којих је дидактика дошла до данашњих дана указује на то да коришћење одређених наставних приступа ученици не само да боље савладавају предвиђене наставне садржаје, већ и да доживљавају веће задовољство наставним часом, као веома важном компонентом за даље учење (Bretz \& Thompsett, 1992, стр. 941-951). Из тог разлога, дидактика се залаже за употребу најразличитијих наставних приступа у настави, односно одабиром адекватног приступа за проучавање одређене наставне јединице.

Знања која ученик стиче се не деле на научне дисциплине, на наставне предмете, већ се уклапају у целовиту слику стварности какву ученик доживљава. Интегративним приступом у настави се таква слика стварности постиже. Њимесе омогућава сагледавање једног проблема са више различитих аспеката. На овај начин се формира један целовит контекст за учење који води дубинском учењу и дугорочном памћењу (Спремић, 2007). Присталице интегративног приступа се залажу за то да границе наставних предмета не би требало да буду границе у организовању наставног процеса (Дробњак, 2007). Многи аутори се залажу за интегративни приступ у образовању и тврде да се софистициранији нивои учења не могу постићи предметном подељеношћу (Klein, 2005). Свакако да у сазнавању у наставном процесу треба подједнако уважавати како аналитички приступ, односно, подељеност на наставне предмете и сазнавање само у оквиру њих, тако и синтетички приступ који 
подразумева стварање нових знања путем сазнања стечених из различитих наставних предмета. Искључиво предметно подељена настава недовољно доприноси стварању целовите слике света и то уз ирационални утрошак времена и енергије, како наставника, тако и ученика. Чињеница да се ученицима омогућава да стичу знања сагледавајући проблем са више страна доприноси већем квалитету знања које је погодно за трансфер и подстиче ученике на активан однос према знању које су стекли (Andrić \& Spasojević, 2012).

Традиционално организована настава која заговара предметну подељеност свакако да има своје предности. Међутим, истраживања су показала да другачији вид организовања наставе доприноси остварењу циљева који су у традиционалној настави занемарени, а данас се постављају као императив. Интегративни приступ, као један иновативни вид организовања наставе, заснива се на уверењу да услови за учење који се њиме остварују, смањују или у потпуности елиминишу традиционалне препреке за учење и омогућавају ученицима да користе не само своје когнитивне потенцијале, већ да остваре дубинско учење (Bretz \& Thompsett, 1992). Познато је да ученици успешније савладавају садржаје уколико су повезани са њиховим искуством и уколико задовољавају њихове потребе и циљеве (Buljubašić - Kuzmanović, 2007). Знања која ученик стиче интергативном наставом су блиска сазнањима која је стекао из сопственог искуства у интеракцији са социјалним контекстом. Целовита слика која се изграђује разумевањем стечених знања ствара код ученика дубинско учење и трајнија знања. Такава знања су драгоцена и погодна за трансфер и практичну употребу.

Практична употреба знања је једна од функција стечених знања. Захтеви који се у савременом свету постављају приликом ступања у свет рада су све комплекснији и захтевају целовита знања и њихово потпуно разумевање. Заговарање образовања у коме се знања парцијално стичу, без увида у целину, не одговарају захтевима савременог друштва. Оно што такође говори у прилог овим чињеницама јесте да су знања подељена на предмете тешко употребљива у практичној (Вилотијевић \& Вилотијевић, 2008). Човек се развија у целовитости и међусобној интеракцији свих елемента. На тим основама треба засновати и систем образовања како би стечена знања била употребљива. Традиционални начин организовања наставе који је заснован на усвајању знања у готовом облику и у оквиру предметне подељености, не може да припреми ученике за захтеве савременог друштва које се трансформише 
великом брзином (Ђорђевић, 2007; Спремић, 2007). Дидктичка вредност интегративне наставе се огледа у функционалности стечених знања и у компетенцијама које се стичу само инсистирањем на оваквом начину сагледавања проучаваног садржаја.

Један од циљева који се постижу интегративним приступом јесте дивергентно мишљење. Дивергентно мишљење тежи ка проналажењу великог броја оригиналних и разноврсних решења. Како би се до овог циља дошло, неопходно је да наставници својим начином рада подстичу ученике да на часу производе што већи број идеја. Интегративним приступом се ученицима омогућава да створе оригиналне идеје решавањем проблемских ситуација, које морају бити подржане од стране наставника. Интегративна настава захтева активног ученика. Она се ни најмање не заснива на преношењу знања, већ у потпуности на решавању проблема, постваљању питања и активном односу према садржајима (Ђорђевић, 2007). Вредност интегративног начина рада се може извести из чињенице да се одређени проблеми не могу решити из перспективе само једне дисциплине (Спремић, 2007). Неопходно је да наставник охрабрује ученике да сагледавају ствари из различитих перспектива и да решавају проблеме на разноврсне начине. Важно је да ученици разумеју да један проблем може потпуно другачије изгледатиуколико ce на њега гледа са више аспеката. Подстицање разумевања подразумева да наставници на часовимаподржавају код ученика могућност да сагледају више перспектива, да преиспитују постојећа знања и да истражују.

Дидактичка вредност интегративног приступа у наставном процесу се огледа у рационалности приликом коришћења времена и средстава у обради наставних тема. За потребеинтегративног приступа врши се тематско планирање. Тематско, интегративно планирање је интердисциплинарно и своди се на тематизацију наставних програма (Вилотијевић, 2000). Тематизација чини оквир за интеграцију наставних садржаја, односно повезује се једно наставно подручје са другим, пружајући могућност сагледавања проблема са свих аспеката. Корелацијом одређених наставних садржаја врши се уштеда времена приликом обраде и доприноси изградњи целовитих природних, друштвених и других подручја. Употребом интегративног приступа се врши оптимизација наставног процеса. У циљу рационализације врши се адекватан избор метода, средстава, облика и поступака, у складу са дидактичко-логичком структуром изабраног градива које се тематски проучава. 
Наведене чињенице говоре у прилог томе да је предметна подељеност какву је заступала традиционална школа запостављала одређене циљеве који су у сваременом друштву неопходни. Интегративна настава је иновативна врста наставе којом се остварује увид у целину и суштину проучаваног садржаја и којом се развијају когнитивне компетенције неопходне за одговор на захтеве савременог друштва. Оно што се намеће као неопходан корак у реализовању интегртивне наставе јесте да се ученици од што млађег узраста навикавају на интегративну наставу и да вреднују сазнања до којих се дође таквим начином рада, и са друге стране, да се повећа сарадња међу наставницима како би се интегративни приступ користио и у предметној, не најчешће у разредној настави.

\section{НЕДОСТАЦИ И ОГРАНИЧЕЬА ИНТЕГРАТИВНЕ НАСТАВЕ}

Дидактичке вредности интегративне наставе се не могу оспорити. Ипак, веома је важно нагласити да је претпоставка остваривања ових вредности не прихватање искључивости и једностраности у приступу настави. Зато се као најчешће ограничење интегративне наставе често наводи опасност од једностраности у погледу заступања искључиво једног приступа у теорији и пракси интегративне наставе (Вилотијевић \& Вилотијевић, 2008; Шефер, 2005; Brophy \& Alleman, 1991, стр. 66-67; Polić, 2006, стр. 61-72). У прилог наведеном јесте чињеница да је наука подељена на научне дисциплине како би се увидела њена логичка структура, и на тој основи се дидактички обликовала и превела на наставне предмете (Шефер, 2005). Циљ проучавања науке у поменутом облику јесте да се код ученика створи логичка струкутра једне науке. У том смислу, Вилотијевић (2006) сматра да потпунији процес диференцијације прати богатија и садржајнија интеграција. Потпуну диференцијацију науке неопходно је да прати процес интеграције како би ученици поред логичке структуре разумели целовито једну науку. Иако се тежи интегралном приступу, човеково сазнање има одређених ограничења која имплицирају на неопходност комбиновања аналитичког и синтетичког сазнања у тежњи за дубинским разумевањем. Осим овог ограничења, међу осталим недостацима могу се издвојити:

1) Умешност и недовољна дидактичко-методична оспособљеност наставника за извођење интегративне наставе. Интегративни приступ у настави поставља захтев 
за ангажованошћу и креативношћу наставника који ће створити једну проблемску ситуацију око које ће се ученици мисаоно ангажовати, путем које ће стећи дубинска и трајнија знања (Jones, 2010). Наставници често не поседују педагошке и дидактичко-методичке компетенције неопходне за успешно планирање и извођење интегративне наставе.

2) Традиционална специјализација у дисциплинама и недовољно познавање других дисциплина представља честу тешкоћу у оставривању интегративне наставе. Наставници често немају шира знања од оних која су им потребна за предмет који предају. Интегративни приступ захтева наставника који: има широку општу културу, добро познаје сродне научне и наставне дисциплине, добро познаје наставни план школе и наставне програме који сеу школи реализују.

3) Тешкоће у остваривању координације међу наставницима, често је препрека у остваривању интегративне наставе. Наставници често нису спремни и немају довољно развијене компетенције да кроз тимски рад обраде одређену наставну тему. Они се тешко прилагођавају новонасталом режиму рада. У том смислу, свакако да је наставницима једноставније да се држе предметне подељености како због неусаглашености програма рада наставника различитих предмета, потребе за модификацијом распореда часова, тако и због припреме за интегративни приступ којој треба посветити више времена (Bretz \& Thompsett, 1992). Истраживање поменутих аутора је показало да су административне промене и ентузијазам наставника довели до бољих резултата у примени интегративног приступа.

4) Неекономичност по питању времена као недостатак интегративне наставе проистиче из сложености њеног планирања и реализовања. Она захтева доста времена и рада на усаглашавању наставних програма, координацији и интеграцији наставних садржаја. Такође, неопходно је одвојити време и за упознавање са објективним и субјективним могућностима ученика, услова рада и могућностима и захтевима својих колега. 
5) Схватање да интегративна настава одузима аутономију наставнику, још једна је тешкоћа оставраивања интегративне наставе. Наставници своју аутономију често доживљавају погрешно придавајући јој најважнију улогу. Тешко се наставници одричу своје примарне улоге и значаја и нису спремни да је деле са другим колегама. Питање аутономије наставника често је повезано са такозваним стучним егозмом који штетно утиче на тимски рад и онемогућава оставривање квалитетне интегративне наставе.

\section{ИМПЛЕМЕНТАЦИЈА ИНТЕГРАТИВНЕ НАСТАВЕ У ШКОЛИ}

Школе већ дуги низ деценија раде по устаљеном, крутом програму који није отворен за промене. Свака новина коју треба увести у наставни процес захтева одређене модификације, односно, обезбеђивање адекватних услова за њену реализацију. Успешна реализација наставног процеса заснованог на интегративном приступу захтева одређене услове, методе и стратегије рада.

С обзиром на то да се већина промена уводи у образовни систем одозго на доле, први и основни корак ка имплементацији интегративне наставе јесте постојање образовне стратегије која ће подржавати интегративни приступ (Ђорђевић, 2007). Чињеница је да у нашој земљи такве концепције нема, те је имплементација препуштена самим наставницима. На њима је да приликом планирања остваре интегративни приступ. Тежње ка интеграцији наставних садржаја и имплементацији овог иновативног модела у настави, препуштене су превасходно ентузијазму учитеља. Учитељи се налазе у повољнијем положају приликом планирања јер они организују целокупну наставу у свом разреду (Дробњак, 2007). То учитељима омогућава да се не морају строго држати распореда часова, већ да ротацијом часова могу спојити више часова и да реализују наставни процес интегративним приступом. Они треба да својим примером служе наставницима предметне наставе како треба остварити интегративну наставу.

Уколико државна концепција не постоји, добар начин за увођење интегративног приступа јесте став који директор школа заузима према овој врсти иновативног рада (Спремић, 2007). Они, заједно са стручним сарадницима, на наставничким већима, могу да 
промовишу овај начин рада и тиме утичу на свест осталих наставника о вредностима интегративне наставе. Такође, они би могли да свој дидактички материјал искористе у циљу помоћи својим колегама у унапређивању свог образовно-васпитног рада. Укљученост великог броја учитеља и наставника оставља више могућности за модификовање распореда часова на задовољство свих (Ђорђевић, 2007).

Конкретан поступак имплементације интегративне наставе јесте планирање образовно-васпитног рада и његова релаизација. С обзиром на то да се интегративни приступ темељи на повезаности више садржаја или више предмета, планирање рада за реализацију интегративне настве, посебно ће бити објашњено.

Планирање интегративне наставе

Настава, најшире схваћена, подразумева темељно планирање и програмирање наставних садржаја. Планирање у настави заснива се на постављању дидактичко-методичких елемената наставног процеса и обезбеђивање неопходних услова како би настава могла да се реализује систематично, организовано и целисходно, у складу са постављеним правилима и принципима у овој области.

Развој наука и њихово диференцирање на научне дисциплине омогућава да се оне дидактички обликују и представе путем појединачних предмета у настави. Међутим, акумулирање научних сазнања доводи до великог броја чињеница које ће се рационалније савладати путем интегацијског приступа. Из тог разлога, у планирању рада треба заступати и тематски, интегративни приступ. Почетни корак у планирању интегративног приступа јесте увид у Школски програм, односно да се стекне увид у објективне и материјалне могућности за извођење интегративне наставе.

Даље, у планирању треба поћи од анализирања Годишњег тематског плана. Као што се може из назива закључити, програми у нашој земљи су тематизовани, односно сачињени од различитих дидактичко-логичких целина. Овај план је оријентационог карактера и садржи опште захтеве којих се треба придржавати у наставном процесу (Вилотијевић, 2000). Њиме се утврђују теме које ће се обрађивати у току године, динамика обраде, потребан број часаова за обраду сваке теме, планирају одговарајуће методе, облици рада и средстава. Овај документ служи наставницима за темељну припрему појединачних, оперативних планова часа. У нашој земљи су 
најзаступљенији месечни оперативни планови који дају реалнију слику шта ће се и на који начин обрађивати у току одређеног месеца.

Примена интегративног методичког приступа у наставном процесу захтева један сасвим нови облик организације и планирања наставе. Различити аутори су имали опречне ставове о планирању интегративне наставе. Према Спасић-Стошић (2016) план рада за припрему и реализацију интегративне наставе треба да прати следеће кораке: избор одговарајуће теме, дефинисање циљева које треба остварити обрадом одређене теме, утврђивање редоследа реализације циљева и појмова које треба обрадити и планирање одговарајућих активности за сваку област, одабир и припрема литературе и другеграђе потребне за реализацију одабране теме, опис активности, оцењивање и закључак о реалаизацији теме. Аутор Валш (Walsh, Čudina-Obradović, \& Hitrec, 2002, стр. 146) наводи да примена интегартивног планирања подразумева: избор одговарајуће теме, покретање олује идеја о садржају наставног пројекта, адекватно познавање садржаја теме, прикупљање материјала потребног за реализацију теме, планирање начина организације наставног часа.

Као што се може закључити,иако аутори различито дефинишу кораке приликом планирања интегративне наставе, углавном су сагласни око процедуре које се треба држати приликом планирања интегративног приступа. Разлика која се може пронаћи код поментурих аутора у планирању интегративне наставе јесте само у детаљној операционализацији наставног часа, односно, у стављању општих назнака везаних за организацију самог часа. Иначе, код оба аутора инсистира се на стваралачком раду ученика који ће на основу искуства, повезивањем садржаја створити велики број идеја које ће проверавати и од наставника добити повратну информацију о разултатима свог рада, о квалитету формираних представа и појмова.

Како Вилотијевић (2006) истиче применом интегративне наставе захтева се планирање часова на којима he ce бити подстакнуто стицање систематичних знања, богаћење искуства, развој креативних активности и формирање вредносних ставова. У односу на дидактичку структуру наставне јединице која је предмет проучавања, захтева се одабир адекватних метода, облика, средстава и поступака. С обзиром на то да је положај ученика интензивно измењен у односу на традиционално организовану наставу, тежи се методама које захтевају активну улогу ученика. Као такве, преовладавају дијалошка метода, или метода разговора, проблемска 
и истраживачка. На њима засноване, као доминантни типови рада у интегративној настави јављају се проблемско, откривачко, искуствено учење и слично.

Наведена организација часа указује на напуштање фронталног облика рада, већ је тежња ка групном облику рада или раду у пару, а затим ка индивидуалном. Стога ауторка Буљубашић-Кузмановић (Buljubašić - Kuzmanović, 2007) истиче да је интегративно учење на почетку, приликом стварања олује идеје, усмерено на групни рад, док касније тежи самосталности и самоодговорности. Часови засновани на интегративном приступу полазе од знања која ученици поседују, од њихових искустава и на њима треба вршити планирање интегративне наставе. Уважавањем принципа од познатог ка непознатом се код ученика се ствара осећај задовољста због доживљаја компетентности на почетку учења које изазива потребу за континуираним учењем.

Повезаност различитих дисциплина и подстицање многобројних способности код ученика обавезује наставнике да при планирању наставе узму у обзир различите медије и изворе сазнавања. Учење може бити обогаћено и учињено занимљивијим уколико се на основу дидактичко-логичке структуре јединице, метода и облика рада изаберу адекватна наставна средстава. У том смислу, као средиште најразличитијих извора, важну улогу у интегративној настави има школска библиотека (Спасић-Стошић, 2016). За усмеравање пажње користе се аудитивна, визуелна и кинетичка чула. Активирањем чула се стичу конкретна знања која богате слику објективне стварности.

На основу наведенихчињеница, јасно се може закључити да је неупоредиво лакше планирати, организовати и реализовати традиционалне облике наставе. Међутим, уколико не занемаримо да је интегративни приступ садржајима од изузетног значаја за остваривање предвиђених наставних циљева, интегративни модел наставе свакако неће изостати из области планирања наставног процеса.

\section{ПОВЕЗАНОСТ ИНТЕГРАТИВНЕ НАСТАВЕ СА ИСХОДИМА УЧЕЬА}

Интегративно учење је, у суштини, синтеза процеса учења кроз вишеструка искуства, обејдињавање значења и стварање нових значења и знања. Питање које се поставља у интегратинвом учењу 
јесте на који начин се оно завршава. Интенционланост сваког процеса учења, па и интегративног, изражена је кроз циљеве и исходе. Исходи учења су јасни описи онога шта ученик траба да зна након одређеног процеса учења. Циљеви зависе од дефиниције исхода, и обрнуто. Комплексне исходе као што је интегративно учење, често је тешко дефинисати речима. Приликом дефинисања исхода, као основни проблем се наводе превише уопштена одређења која се практично не могу проверити. Они се могу дефинисати оперативно, односно, одредити шта треба радити када се тежи одређеном исходу. Сваки задатак се може доделити неком исходу (Huber, Hutchings, Gale, Miller, \& Breen, 2007). Потребно је ангажовати стручњаке из сваке области који ће исходе процеса интегративног учења оперативно дефинисати. У овом раду, исходи учења оставрени интегративним приступом сагледаваће се кроз дидактичке вредности интегративне наставе, односно кроз њихову операционализацију сходно проучаваној теми. Исходи, односно резултати, који се постижу интегративном наставом се пре свега огледају у целовитом сагледавању проблема, из више перспектива и практичној употреба знања.

Истраживања аутора Химбулт-Тејлора (Himbeault Taylor, 2011) указују на то да се есенцијални исходи учења темеље на организовним процесима интегративног учења. Другим речима, као што је у претходним деловима рада наведено, интегративна настава почива на искуствима и предзнањима ученика које проузоркује примарне резултате процеса учења и на тај начин доприноси задовољству и континуираном учењу. У конкретним условима, на наставном часу, ово се постиже изражавањем планираних исхода учења, стварањем интенцијално структуираних прилика за учење да би се исходи остварили и постигло активно размишљање и да би се стечено знање повезивало са искуством. Интегративном наставом нуди се могућност преплитања различитих исхода као што је решавање проблема или критичко размишљање, као и утврђивање веза и односа између дисциплина (Huber \& Hutchings, 2004) .

Као једна од дидактичких вредности која се истиче применом интегративне наставе јесте дубинско учење. Неколико студија указују на то да у комплексним областима интегративно засновано, дубинско учење, позитивно делује на исходе учења, а да као резултат у тим областима имају измењену наставну праксу, повећану употребу знања и самим тим побољшане резултате (Laird, Shoup, Kuh, \& Schwarz, 2008). Уколико је у учењу укључена когнитивна, 
афективна и искуствена димензија, то је већа вероватноћа да ће садржаји постати истински интегрисани (Himbeault Taylor, 2011). Овај аутор наводи како значајну улогу у промовисању интегративног учења има управо побољшање исхода учења. Уколико се интегративни приступ покаже бољим у остваривању циљева и исхода образовно-васпитног процеса од традиционалог приступа наставном процесу, наставници и сами ученици биће мотивисанији за имплементацију интегративне наставе.

Може се закључити да се вредности интегративне наставе у погледу исхода учења могу сагледати преко практичне провере постављених задатака, од којих сваки задатак одговара одређеном исходу. Постављање великог броја комплексних исхода захтева од реализатора наставног процеса да томе прилагоде типове часова, методе и облике рада. Интегративна настава може да одговори на захтеве у погледу остварања исхода образовно-васпитног процеса јер у њеној реализацији код ученика синтетише когнитивну, емоционалну, социјалну и радно-активну компоненту.

\section{ЗАКЉУЧАК}

Претпоставка ефикасности савремене наставе јесте њено утемељивање на савременим моделима наставе и развојном моделу образовања. Један од савремених модела наставе који обезбеђује квалитет и ефикасност наставног рада јесте интегративна настава. Подразумевајући сагледавање различитих димензија једног проблема, са различитих страна и из различиитих углова, интегративна настава подразумева: активно учење, дугорочно запамћивање и повезивање знања у смислени систем, тј. целину. Одбацујући традиционалну предметну подељеност наставних садржаја, интегративна настава подразумева тематски приступ и проблемско учење у настави. Ученици тако у настави стичу целовита знања и развијају функционалне способностишто је основа за потпуни развој личности. Адекватним планирањем, програмирањем и реализовањем интегративне наставеусвајају се дубинска знања, спречава заборављање, развијаја активистички став, креативни и стваралачки потенцијали ученика и формира целовити поглед на свет. Као што смо у раду видели, дидактичке вредности интегративне наставе су велике и често нису својствене другим моделима наставе. Оно што је важно нагласити јесте чињеница да је за ефикасност интегративне наставе пресудно и добро познавање њених основних 
препрека односно тешкоћа које се могу јавити, те оспособљавање актера наставног процеса да их адекватним дидактичко-методичким поступцима успешно превазиђу. Савремени изазови интегративне наставе, сагледани у раду кроз основне карактеристике, дидактичке вредности, недостатке, имплементацију у настави и повезаност са исходима наставе, основа су на којој наставници практичари могу темељити неопходне компетенције интегративног наставног рада.

\section{ЛИТЕРАТУРА}

Вилотијевић, М. (2000). Дидактика 3- Организација наставе. Београд: Научна књига; Београд: Учитељски факултет.

Вилотијевић, М., \& Вилотијевић, Н. (2008). Иноващије у настави. Врање: Учитељски факултет.

Вилотијевић, Н. (2006). Интегративна настава природе и друштва. Београд: Школска књига.

Дробњак, Н. (2007). Интегративна настава. Образовна технологија, 12, 81-91.

Ђорђевић, В. (2007). Иновативни модели наставе. Образовна технологија, 4, 76-97.

Спасић-Стошић, А. (2016). Улога школске библиотеке у реализацији интегративне наставе у основној школи. Годишњак Педагошког факултета у Врању, 7, 381-392. 2, 74-80.

Спремић, А. (2007). Интегративна настава. Образовна технологија, 1-

Шефер, J. (2005). Креативне активности у тематској настави. Београд: Институт за педагошка истраживања.

Andrić, V., \& Spasojević, P. (2012). Korelacija nastave matematike i ostalih nastavnih oblasti u mlađim razredima osnovne škole. U: N. Vulović (Ur.), Metodički aspekti nastave matematike 2, Jagodina. Fakultet pedagoških nauka.199-212.

Bretz, R.D., \& Thompsett, R.E. (1992). Comparing traditional and integrative learning methods in organizational training programs. Journal of Applied Psychology, 77(6), 941-951. pmid:1468996. doi:10.1037/00219010.77.6.941

Brophy, J., \& Alleman, J. (1991). A caveat: Curriculum integration isn't always a good idea. Educational Leadership, 49(2), 66.

Buljubašić-Kuzmanović, V. (2007). Studentska prosudba učinkovitosti integrativnog učenja. Odgojne znanosti, 9(2(14)), 147-160. Preuzeto sa http://hrcak.srce.hr/23550 
Himbeault Taylor, (. (2011). Engendering habits of mind and heart through integrative learning. About Campus, 16(5), 13-20. doi:10.1002/abc.20076

Huber, M.T., \& Hutchings, P. (2004). Integrative Learning: Mapping the Terrain. Washington, DC: Association of American Colleges and Universities. Preuzeto sa https://eric.ed.gov/?id=ED486247

Huber, M.T., Hutchings, P., Gale, R., Miller, R., \& Breen, M. (2007). Leading Initiatives for Integrative Learning. Liberal Education, 93(2), 46-51.

Jones, C. (2010). Interdisciplinary Approach: Advantages, Disadvantages, and the Future Benefits of Interdisciplinary Studies. ESSAI, 7(1), 76-81.

Klein, J.T. (2005). Integrative learning and interdisciplinary studies. Peer Review, 7(4), 8-10.

Laird, T.F.N., Shoup, R., Kuh, G.D., \& Schwarz, M.J. (2008). The Effects of Discipline on Deep Approaches to Student Learning and College Outcomes. Research in Higher Education, 49(6), 469-494.

Polić, M. (2006). Integralna nastava kao odgovor na suvremene obrazovne potrebe. Metodički ogledi : časopis za filozofiju odgoja, 12(2), 61-72.

Walsh, K.B., Čudina-Obradović, M., \& Hitrec, G. (2002). Stvaranje razreda usmjerenog na dijete - kurikulum za prvi razred osnovne škole razvojno-primjereni program za djecu od 6 do 7 godina - priručnik br. 4. Zagreb: Udruga roditelja "Korak po korak" za promicanje kvalitete življenja djece i obitelji.

\title{
CONTEMPORARY SOCIETY CHALLENGES OF INTEGRATIVE TEACHING
}

\author{
Marija, M. Jovanovic ${ }^{1}$,Vesna, S. Kovcic ${ }^{2}$
}

Abstract: This paper discusses the characteristics of integrative teaching as an innovative teaching model which creates opportunities for comprehensive development of the student's personality through the adoption of comprehensive knowledge and development of functional abilities of students. Based on the principle of functional connectivity of meaningful, cognitive, psychological, organizational and sociological aspects of teaching, integrative teaching offers many opportunities for good quality educational activities. However, the complexity that arises from the abovementioned traits of integrative teaching entails some difficulties in the process of its planning, programming and implementation. It is important for the teaching process to have a good

\footnotetext{
${ }^{1}$ marija.jovanovic@ filfak.ni.ac.rs, University of Niš, Faculty of Philosophy

2 vesnakovcic93@gmail.com, University of Niš, Faculty of Philosophy
} 
knowledge of the essential characteristics and values of integrative teaching and a willingness to use successful didactic and methodical tools to overcome potential difficulties. In order to systematically emphasize the current challenges of integrative teaching, this paper approached this problem from the aspect of: theoretical definitions, didactic values, disadvantages, the implementation of integrative teaching in schools, and how integrative teaching helps students to acquire knowledge.

Key terms: didactic values; implementation; knowledge; Learning outcomes; integrative teaching.

Примљен: 25.4.2017.

Прихваћен: 8.5.2017.

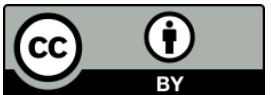

